\title{
Contextual Factors and Strategic Consequences of Cloud Enterprise Resource Planning (ERP) Adoption in Malaysian Manufacturing SMEs: A Conceptual Framework
}

Submitted 14/03/20, 1st revision 09/04/20, 2nd revision 18/05/20, accepted 20/07/20

\author{
Olakunle Jayeola ${ }^{1}$, Shafie Sidek ${ }^{2 *}$, Azmawani Abd Rahman ${ }^{3}$, \\ Anuar Shar Bali Mahomed ${ }^{4}$, Hu Jimin ${ }^{5}$
}

Abstract:

Purpose: The purpose of this study is to holistically investigate the interrelationships between key contextual factors of cloud ERP adoption and the strategic consequences of such adoption. Design/Methodology/Approach: The key contextual factors whose influences are explored on cloud ERP adoption are Feature task-match, (FTM); Top Management Support on Change Management (TMSCM) and Government Financial Support (GFS) while the strategic consequences of cloud ERP adoption investigated are competitive advantage (CA) and organisational performance. A conceptual framework grounded in Technology-OrganisationEnvironment (TOE) model, Task technology-fit (TTF) model and Resource-Based View (RBV) theory is developed for empirical validation that will involve a projected sample of 382 respondents of SMEs in Malaysia using PLS-SEM as main statistical analysis tool.

Practical Implications: Practically, this study will guide SMEs' managers on cloud ERP selection that fits their firms' tasks, how to effectively deal with resistance to change occasioned by technology adoption and how effective GFS has been influencing cloud ERP adoption. In addition, SMEs managers stand to gain insight into how cloud ERP adoption can simultaneously and/or indirectly lead to competitive advantage and organisational performance as strategic benefits.

Originality/Value: Investigation of a new variant key contextual factors critical for successful cloud ERP adoption and their subsequent impact on CA and organisational performance simultaneously and indirectly.

Keywords: Contextual, cloud ERP, adoption, Malaysia, SMEs, strategic consequences.

JEL Code: L25, L60, M21.

Paper Type: Research study.

\footnotetext{
${ }^{1}$ Adekunle Ajasin University, olakunlejayeola@gmail.com

${ }^{2}$ Universiti Putra Malaysia, shafiesidek@upm.edu.my

${ }^{3}$ Universiti Putra Malaysia, azar@upm.edu.my

${ }^{4}$ Universiti Putra Malaysia, anuar@upm.edu.my

${ }^{5}$ Ganzhou Teachers College, chrishu21@foxmail.com
} 


\section{Introduction}

The present rapid economic development poses a threat to firms and in order to survive the ravaging competition triggered by this swift economic progression, they must adopt emerging innovation (Arteta and Giachetti, 2004; Roberts and Grover, 2012). Among the popular emerging innovative technologies that are reshaping the business world is cloud computing (CC). $\mathrm{CC}$ is a technology which facilitates the outsourcing of information technology (IT) by obtaining computing resources on the internet through pay-per-use model (Martson, Bandyopadhyay, Zhang, and Ghalasi, 2011; Yigitbasioglu, 2015). CC is made up of three main services, namely; Software as a Service (SaaS), which enables user to access software applications, Infrastructure as a Service (IaaS), which provides networks, operating systems, virtual machine, servers and storage, and Platform as a Service (PaaS), which permits users to experiment and deploy software. CC has four deployment models; private (solely for one organisation), public (shared by many organisations), community (exclusively for firms that have shared interests and hybrid cloud (combination of two or more models) (Bruque-Cámara, Moyano-Fuentes, and Maqueira-Marín, 2016; Mell and Grance, 2011; Vu, Hartley, and Kankanhalli, 2020). According to Gartner (2018), by 2022, over $\$ 1.3$ trillion of global IT expenditure will be fully or partially influenced by cloud implementation. In Malaysia, IDC predicts that by 2023, cloud-based services market will have an accumulated yearly growth rate of 23.8\% (Reseller Malaysia, 2018).

SMEs prevalently leverage on CC as it is less-expensive than setting up local servers and it empowers local firms to connect and compete globally (Hasnan, 2019). CC can improve SMEs' competitiveness by expediting business operations, saving money on computing cost, optimally accelerating time to market and consequently improving the bottom line of businesses (Amini and Bakri, 2015; Abolfazi et al., 2015). Business applications offered on CC include supply chain management (SCM), customer relationship management (CRM), enterprise resource planning (ERP) and more. These applications are usually offered as software-as-a-service (SaaS). As a result, many SMEs can afford to subscribe because it is cheap, scalable and pay per use (Marston et al., 2011; Son, Lee, Lee, and Chang, 2014; Yu, Li, Li, Zhao, and Zhao, 2018). Out of these CC business applications, cloud ERP is of interest to this study since it enables organisations to gain from a powerful integration of information and processes across diverse functions of business (OECD, 2019). Cloud ERP is an organisational-wide Information System (IS) packages that comprise of a broad collection of software modules designed to harmonize the vital logistics in business processes across several functional units and department of organisations through one data storage (Rezaei, Karimi, and Hosseini, 2016).

The global cloud ERP market is predicted to reach $\$ 40.5$ by 2025 , increasing between 2019 and 2025 at a CAGR of $13.6 \%$ (Liu, 2020). The cloud-based ERP systems are germane for all SMEs because they allow them to conduct data transactions along the value chain and help simplify information between finance, inventory, planning, manufacturing, human resources, marketing, engineering, distribution, materials and 
sales and all other units within the organisation and among other organisations (AlShboul, 2018; Khamis and Mohd, 2016).

SMEs all over the world play a significant role in the economies of their host countries. In Malaysia, SMEs comprise of $98.5 \%$ of all business population and in 2018, they contributed $38.3 \%, 17.3 \%$ and $66.2 \%$ to the overall GDP, total exports and employment respectively (Teng, 2020). For global competitiveness and economic sustainability, Malaysian government has taken some measures to assist SMEs in forms of policies and incentives towards CC adoption. For instance, the digital transformation of the economy through endeavours such as education and awareness campaigns and the Malaysia Multimedia Super Corridor (MSC) Malaysia Cloud Computing Enablement Initiative (Mehrotra, 2017). Similarly, through the Multimedia Development Corporation (MDeC), Malaysia government offers SMEs a six-month subscription fee refund or up to RM1,500 of the total amount of subscription for any type of Saas such as cloud ERP from any of the Malaysia MSC status companies (Hassan, 2017: Hassan, Mohd Nasir, Khairudin, and Adon, 2017).

Despite government's effort, evidence shows that cloud-based applications are on the low side. For example, according to the digitalisation Survey of SMEs in 2018 by SME Corp. Malaysia and Huawei Technologies (M) Sdn. Bhd, only 44\% SMEs in Malaysia have adopted CC, out of which $35 \%$ use other business applications and 10.5\% use cloud ERP (Lee, 2018; Noordin, 2019; SME Corporation and Huawei Technologies, 2018). Malaysian SMEs' lag in cloud adoption begs the question. Prior studies largely concentrated on some factors influencing CC/cloud ERP adoption with inadequate consideration given to vital contextual factors influencing CC/cloud ERP adoption (Asiaei, Zairah, and Rahim, 2019; Fook Ming, Kim On, Rayner, Tse Guan, and Patricia, 2018; Qian, Bahrudin, and Kanaan-Jebna, 2016).

Additionally, prior studies show tendency not to investigate the strategic consequences of adopting $\mathrm{CC}$ when examining its antecedents. This research seeks to holistically study this phenomenon by comprehensively investigating the interconnection between vital contextual factors (feature-task match, FTM, top management support on change management, TMSCM and government financial support, GFS) of cloud ERP adoption and the strategic consequences; competitive advantage (CA) and firm performance resulting from such adoption. Prominently, this study seeks to develop a conceptual model that will serve as a guideline for successful cloud ERP adoption and strategic consequences of such adoption by SMEs.

The paper's structure is as follows. The next section gives the theoretical background of the study. Then the literature review of contextual factors and strategic consequences are discussed in the third section. Research framework and hypotheses development and research methodology are presented in sections 4 and 5 . The discussion and conclusion section ends the paper. 


\section{Theoretical Background}

In contrast to predominant focus on adoption as found in the literature, this study integrates both vital contextual factors and strategic consequences of cloud ERP adoption. The contextual factors influencing cloud ERP adoption is grounded in the TOE model (Tornatzky and Fleischer, 1990) and the technology context of the TOE is anchored by the Task-technology fit (TTF) theory of Goodhue and Thompson (1995). The strategic consequences of cloud ERP adoption is underpinned by the Resource-based view (RBV) theory (Barney, 1991). The next section discusses the theoretical foundation of this study.

\subsection{The TOE Framework}

According to Tornatzky and Fleisher (1990), TOE consists of three forms of an organisation's contexts that influence how technological innovations are implemented; they are the technological, organisational and environmental contexts. The technological context illustrates both the accessible technologies and the latest ones in the organisation. The descriptive elements of a firm such as size, scope and the quantity of excess resources available within are the organisational context. The external surrounding in which a firm operates - competitors, its industry, and connection to government refers to environmental context. TOE provides a good foundation when examining appropriate adoption factors and innovation utilisation because of its high empirical validation (Wang, Wang, and Yang, 2010; Zhu and Kraemer, 2005). The organisational, environmental and technological factors inclusion in TOE makes it have an edge above other adoption models in investigating adoption, usage and creation of value of new technology (Hossain and Quaddus, 2011; Oliveira and Martins, 2010; Zhu and Kraemer, 2005).

\subsection{The Task-Technology Fit (TTF) Theory}

TTF theory, proposed by Goodhue and Thompson (1995), posits that how well the requirements of a job match the features of a new technology determines technology acceptance. Essentially, Goodhue and Thompson (1995) and D'Ambra and Wilson (2013) argue that TTF is a factor that clarifies the degree to which IT can improve workers task, that is to say, the higher the harmony between technology and tasks, the higher the employees' performance. TTF highlights the interconnections between an individual, task and technology. Tasks are generally defined as the actions performed by persons in processing inputs into outputs. A task characteristics comprise those that might make a user to depend greatly on certain components of an IT. Technologies are regarded as instruments used by people to execute their given tasks. In the perspective of IT studies, technology includes computer systems (software, hardware, and data) and back-up services for user (such as training) made available to help users in their tasks. Individual characteristics (such as instruction, computer skills and drive) could dictate how effective the person will put the technology to use. Diverse tasks require diverse technological applicabilities. The wider the gap between the task 
requirements and the applicability of a technology, the lesser TTF (Goodhue and Thompson, 1995) and vice-versa.

\subsection{Combining TOE and TTF}

Wang et al. (2010) and Gangwar, Date and Ramaswamy (2015) argue that TOE framework has unclear major constructs and is too generic, hence it needs to be reinforced by integrating with the theories that have plain constructs. In addition, Awa, Baridam and Nwibere (2015), Henderson, Sheetz and Trickle (2012) and Premkumar (2003) advocated that to determine the fundamental relationships and discover the precise factors that exist among the three contexts of TOE, it should be integrated with other theories of technology acceptance that suggest task and individual contexts so that predictive power of the resulting model can be improved. In this regard, the TOE framework is somewhat quiet on how technology's functionality match the task needs of the end-users (Awa, Ojiabo, and Orokor, 2017; Balaid, Abd Rozan, and Abdullah, 2014) making TTF an appropriate complementary theory. Thus, as a supporting theory to the TOE framework, the feature-task match (FTM), coined from the TTF is used to represent the technology factor of the TOE.

After taking into consideration prior CC studies' neglect of integrating TTF with TOE as shown in Table 1and section 3.1.1, the limited efforts of investigating a critical factor, top management support on change management, see Table 1 and section 3.1.2 and the fuzzy investigation of government support without clearly differentiating government non-financial support from government financial support, see Table 1 and section 3.1.3, the technology factor- Feature-task match (FTM), organisation factor, Top management support on change management (TMSCM) and environment factorGovernment financial support (GFS) are selected as key contextual factors for cloud ERP adoption.

Table 1. Literature on cloud computing adoption based on TOE model

\begin{tabular}{|l|l|l|l|}
\hline $\begin{array}{l}\text { Authors/year/industry/coun } \\
\text { try }\end{array}$ & $\begin{array}{l}\text { Technology } \\
\text { context factors }\end{array}$ & $\begin{array}{l}\text { Organisation } \\
\text { context factors }\end{array}$ & $\begin{array}{l}\text { Environment } \\
\text { context factors }\end{array}$ \\
\hline $\begin{array}{l}\text { Gutierrez, Boukrami and } \\
\text { adoption. (2015). CC } \\
\text { enterprises (Multi-industry). } \\
\text { UK }\end{array}$ & $\begin{array}{l}\text { Relative advantage, } \\
* \text { complexity and } \\
\text { compatibility }\end{array}$ & $\begin{array}{l}\text { Top management } \\
\text { support, firm size } \\
\text { and *technology } \\
\text { readiness. }\end{array}$ & $\begin{array}{l}\text { *Competitive } \\
\text { pressure and } \\
* \text { trading partner } \\
\text { pressure. }\end{array}$ \\
\hline $\begin{array}{l}\text { Oliveira, Thomas and } \\
\text { Espadanal (2014). CC } \\
\text { adoption. Large and small } \\
\text { enterprises (manufacturing } \\
\text { and services). Portugal. }\end{array}$ & $\begin{array}{l}\text { *Technology } \\
\text { readiness, *relative } \\
\text { advantage, } \\
* \text { complexity and } \\
\text { compatibility. }\end{array}$ & $\begin{array}{l}* \text { Top management } \\
\text { support and *firm } \\
\text { size }\end{array}$ & $\begin{array}{l}\text { Competitive } \\
\text { pressure and } \\
\text { regulatory support. }\end{array}$ \\
\hline $\begin{array}{l}\text { Karkonasasi et al. (2016). CC } \\
\text { adoption. SMEs. Malaysia. }\end{array}$ & $\begin{array}{l}* \text { Cost saving, } \\
\text { *security and } \\
\text { privacy and } \\
\text { reliability. }\end{array}$ & $\begin{array}{l}* \text { Top management } \\
\text { support. }\end{array}$ & $\begin{array}{l}\text { *Competitive } \\
\text { pressure and } \\
* \text { trading partner } \\
\text { pressure. }\end{array}$ \\
\hline
\end{tabular}




\begin{tabular}{|c|c|c|c|}
\hline $\begin{array}{l}\text { Asiaei et al. (2019). CC } \\
\text { adoption. SMEs. Malaysia. }\end{array}$ & $\begin{array}{l}\text { *Data security, } \\
* \text { technology } \\
\text { readiness and cost } \\
\text { saving. }\end{array}$ & $\begin{array}{l}* \text { Top management } \\
\text { support and } \\
* \text { innovativeness. }\end{array}$ & $\begin{array}{l}* \text { Competitive } \\
\text { pressure and } \\
\text { regulatory support. }\end{array}$ \\
\hline $\begin{array}{l}\text { Qian et al. (2016). Cloud ERP } \\
\text { adoption. SMEs. Malaysia. }\end{array}$ & $\begin{array}{l}\text { Security and } \\
\text { privacy, cost } \\
\text { effectiveness and } \\
\text { internet reliability. }\end{array}$ & $\begin{array}{l}* \text { Top management } \\
\text { support. }\end{array}$ & $\begin{array}{l}\text { Competitive } \\
\text { pressure. }\end{array}$ \\
\hline $\begin{array}{l}\text { Fook Ming et al. (2018). CC } \\
\text { adoption. SMEs. Malaysia. }\end{array}$ & $\begin{array}{l}\text { *Cost saving, } \\
* \text { technology } \\
\text { readiness and } \\
\text { relative advantage. }\end{array}$ & $\begin{array}{l}\text { *Top management } \\
\text { support. }\end{array}$ & $\begin{array}{l}\text { Competitive } \\
\text { pressure and } \\
\text { external support. }\end{array}$ \\
\hline $\begin{array}{l}\text { AL-Shboul (2018). Cloud } \\
\text { ERP adoption. SMEs. } \\
\text { International }\end{array}$ & $\begin{array}{l}* \text { Technology } \\
\text { readiness, security } \\
\text { concerns and } \\
\text { *technical barriers. }\end{array}$ & $\begin{array}{l}\text { *Top management } \\
\text { support, *enterprise } \\
\text { readiness, } \\
\text { *enterprise size and } \\
\text { enterprise status. }\end{array}$ & $\begin{array}{l}\text { *Competitive } \\
\text { pressure, } \\
\text { government support } \\
\text { and } \\
\text { infrastructure/teleco } \\
\text { mmunication. }\end{array}$ \\
\hline $\begin{array}{l}\text { Hsu and Lin (2016). Cloud } \\
\text { services adoption. Large and } \\
\text { small enterprises (Multi- } \\
\text { industry). Taiwan. }\end{array}$ & $\begin{array}{l}\text { *Relative } \\
\text { advantage, ease of } \\
\text { use, compatibility, } \\
\text { trialability, } \\
\text { *observability and } \\
\text { *security. }\end{array}$ & $\begin{array}{l}\text { Firm size, global } \\
\text { scope, *financial } \\
\text { costs and } \\
\text { *satisfaction with } \\
\text { existing IS. }\end{array}$ & $\begin{array}{l}\text { *Competition } \\
\text { intensity and } \\
\text { regulatory } \\
\text { environment. }\end{array}$ \\
\hline $\begin{array}{l}\text { Khayer,Talukder, Bao and } \\
\text { Hossain (2020). CC adoption. } \\
\text { SMEs. Bangladesh. }\end{array}$ & $\begin{array}{l}\text { Relative advantage, } \\
\text { service quality and } \\
\text { perceived risk. }\end{array}$ & $\begin{array}{l}\text { Top management } \\
\text { support and } \\
\text { facilitating } \\
\text { conditions. } \\
\end{array}$ & $\begin{array}{l}\text { Cloud providers' } \\
\text { influence and server } \\
\text { location. }\end{array}$ \\
\hline $\begin{array}{l}\text { Amini and Bakri (2015). CC } \\
\text { adoption. SMEs. Malaysia. }\end{array}$ & $\begin{array}{l}{ }^{*} \text { Relative advantage, } \\
\text { *compatibility, } \\
\text { "security concerns, } \\
\text { *cost savings and } \\
\text { "technology } \\
\text { readiness. }\end{array}$ & $\begin{array}{l}\text { "Top management } \\
\text { support }\end{array}$ & $\begin{array}{l}{ }^{*} \text { Competitive } \\
\text { pressure and } \\
\text { "regulatory support }\end{array}$ \\
\hline
\end{tabular}

Note: * Significant factors.

Source: Compiled by authors.

\subsection{Resource-Based View (RBV) Theory}

The RBV takes a holistic view on why firms thrive or are unsuccessful in the market arena (Dicksen, 1996). Based on the RBV theory, an organisation can be referred to as a mix of physical, human and organisational resources (Amit and Schoemaker, 1993; Barney, 1991). The RBV theory contrives an idea or gives an explanation of tangible and intangible resources as well as capabilities which have impactful influence on organisation performance (Kamasak, 2017). The tangible and intangible resources that are valuable, rare, inimitable and non substitutable (VRIN) (Barney, 1991) facilitate firms to grow and maintain competitive advantages, to make use of these resources and competitive advantages for better-quality results (Madhani, 2010; Grant, 1991; Wernerfelt, 1984). Based on RBV theory (Barney, 2001), competitive advantage could be gained by a firm through resources and capabilities combination (Gupta, Qian, Bhushan, and Luo, 2018). The tactical combination of resources and 
capabilities espouses uniqueness of strategy, difficult to copy by other firms. Organisational competitive advantage has been examined through RBV lens and RBV has been used by many researchers investigating firm performance (Azam, 2015).

Cloud ERP is such a strategic instrument for helping firms to achieve competitive advantages by combining all business processes, honing the available resources, improving accessibility, facilitating market reach, and enhancing productivity and efficiency (Gupta, Kumar, Singh, Foropon, and Chandra, 2018; Nikookar, Yahya Safavi, Hakim, and Homayoun, 2010; Zamzeer et al., 2019). RBV theory provides a theoretical base for linking CC adoption with firm performance (Gangwar, 2017; Garrison, Wakefield, and Kim, 2015; Gupta, Kumar et al., 2018) and competitive advantage. Thus, in this study, cloud ERP serves as IT resources and cloud ERP adoption conceptualised as usage and strategic alignment represents the firm's capabilities. The combination of these two encapsulates the VRIN qualities (Barney, 1991) and allows firms to gain strategic benefits of CA and better organisational performance.

\section{Literature Review on Key Contextual Factors and Strategic Consequences of Cloud ERP Adoption}

As earlier explained, three unique factors of the TOE framework, FTM, TMSCM and GFS are selected as the contextual factors of cloud ERP Adoption based on prior studies' neglect of these crucial factors and Competitive advantage (CA) and organisational performance are the strategic consequences of cloud ERP adoption focused in this study, since studies have confirmed that they are the two dominant strategic benefits firms seek in IT adoption (Bruque-Camara et al., 2016; Chang, Hsu, Huang, and Chen, 2019; Lucia-Palacios et al., 2014; Shehat and Montash, 2019). These constructs are reviewed in the next section.

\subsection{Contextual Factors of Cloud ERP Adoption}

\subsubsection{Feature-Task Match (FTM)}

FTM is the reasonable perspective of how a novel technology's capacity can support the effective and efficient performance of a task. TTF (Goodhue and Thompson, 1995) is among the theories of IS with behavioural technique that explains tasks compatibility with IS technologies (Ratna, Astuti, Utami, Rahardjo, and Arifin, 2018). Based on TTF theory, digital technologies such as cloud ERP are more likely to yield a positive effect when the functionalities they deliver can match the tasks organisational users must undertake (Goodhue and Thompson, 1995). In this study, FTM is synonymously referred to TTF. Ghani, Di, Khidzir, Guan and Ismail (2017) integrated FTM and TBP to investigate the intention of textile cyberpreneurs to implement m-retail application based in the cloud in Malaysia. They found FTM as the most influential factor on textile cyberpreneurs' behavioural intention to use cloudbased m-retail application. 
Furthermore, Cheng (2019a) in the cloud ERP context in Taiwan found FTM to have significant effects on, perceived usefulness, users satisfaction and confirmation which in turn led to cloud ERP usage continued intention. FTM, expectation-confirmation model (ECM) and DeLone and Mc Lean information system success (D\&M) models were applied. Abugabah, Sanzogni and Alfarraj (2015) investigated ERP's impact on users' performance in six universities in Australia. FTM was combined with TAM and D\&M's models. FTM significantly contributed to users' performance success of ERP measured by efficiency, effectiveness and service quality. On the other hand, Cheng (2019b) found FTM to have significant influence on users' satisfaction, confirmation and perceived usefulness with the cloud e-learning system in a Taiwanese university based on the theoretical foundation of FTM and ECM. Despite the importance of FTM to complement TOE, the literature review revealed that studies which strengthens the TOE framework with FTM in the cloud-based services adoption are scant.

\subsubsection{Top Management Support on Change Management (TMSCM)}

Top management support is as a result of the fact that the conviction and willingness of top management to endorse adequate financial resources, technological competencies and human resources is vital for facilitating successful $\mathrm{CC}$ adoption (Hassan et al., 2017). Top management will be motivated to ensure that all kinds of resources needed to adopt $\mathrm{CC}$ successfully or expand its usage are provided when they are aware of its benefits (Oliveira et al., 2014; Pathan et al., 2017). Similar to onpremise ERP solutions, the adoption of cloud-based ERPs leads to organisational changes (Elragal and El Komos, 2012). Though cloud ERP can be quickly implemented, it still requires significant time for organisational adaptations, where staff must amend some of their routines in order to handle data in a different way (SØrheller, HØvik, Hustad, and Vassilakopoulou, 2018). Organisational resistance has been a factor that SMEs battle with when moving from conventional means of conducting the business to cloud-based ERP solution (Gupta and Misra, 2016). Thus, a call for proper change management by top management to curtail resistance. Past studies on CC/cloud ERP have been able to confirm the influence of TMS on CC adoption (AL-Shboul, 2018; Asiaei et al., 2019; Fook Ming et al., 2018; Karkonasasi et al., 2016; Oliveira et al., 2014; Qian et al., 2016).

However, none of these studies used instruments that completely reflect TMS complexity and multi-dimensionality such as structural arangements, communication, expertise, power or authority, resources provision, change management and more (Ahmed and Azmi bin Mohamed, 2017; Boonstra, 2013; Dong, Neufeld, and Higgins, 2009). For example, Qian et al. (2016) used five items of "top management deems cloud ERP is essential in the operations of company", "the decision of top management is vital for company to adopt cloud ERP", "top management plans to adopt cloud ERP", "top management will support cloud ERP adoption", and "top management support is important to provide resources for comapany to adopt cloud ERP". Oliveira et al. (2014) used three items "the company's management supports the implementation of cloud computing", "the company's top management provides strong leadership and engages in the process when it comes to information systems" 
and "the company's management is willing to take risks (financial and organisational) involved in the adoption of cloud computing". Qian et al. (2016) literally measured the attitude of top management towards cloud ERP adoption and Oliveira et al. (2014) measured TMS as top management behaviourial action of "support" as a general concept, "strong leadership" and attitude of top management "willingness". These items partially measure TMS and may be misleading as they insinuate all the existing types of TMS and moreover they are devoid of TMS on change management, a vital role for successful IT adoption.

Change is a compulsory situation in adopting $\mathrm{CC}$ and resistance to change has been reported as a barrier to adopting and using CC (Gangwar, 2017; Hsu and Lin, 2016; Yeboah-Boateng and Essandoh, 2014). However, TMS on change management has been neglected altogether in the literature. According to a 2014 report "Best Practices in Change Management" by a world renowned change management research group Prosci, there was a finding that an IT project is $600 \%$ more likely to be successful when an excellent change management is put in place by organisational leaders (Wipfli LLP, 2014). In actual fact, the discussion of change hardly exists without implicitly making reference to leadership (Bass, 2008), yet, close relationships between change and leadership have not been systematically explored (Oreg and Berson, 2019). This study therefore seeks to investigate the TMS role of managing change during $\mathrm{CC}$ adoption.

\subsubsection{Government Financial Support (GFS)}

Government support (GS) could be direct investments, financial incentives, specific suggestions to firm's business activities and business-friendly programs and policies (Wang, Xue, Liang, Wang, and Ge, 2019) that can influence IT adoption such as cloud ERP. Thus, a firm's behaviour and competitiveness could be greatly affected by various degrees of support from government (Cai, Jun, and Yang, 2010). Basically, GS is conceptualised as financial and non-financial supports (Kim, Oh, Park, and Joo, 2018). An observation from prior studies in the CC domain in Table 1 shows that the generic GS concept was employed. A more critical scrutiny of the measurement items revealed that some authors only focused on non-financial support without the financial support. For example Oliveira et al. (2014) conceptualised GS from the non-financial view, using 2 instrument items of "legal protection in using $\mathrm{CC}$ " and "the sufficiency of present laws and regualtions to protect CC usage". Sandu and Gide (2018) employed five items which are "regulation of data protection policies for CC", "sufficiency of current laws and regualtions for CC usage", "sufficiency of current laws and regualtions for $\mathrm{CC}$ user's interest", "support of business laws for CC" and "provision of incentives for CC usage" where only the last item indifferently highlights GFS which can still be disputed as not GFS because incentives could be non-financial.

It is argued that the indiscriminatory investigation of the GS concept maybe responsible for the conflicting results reported in the literature. For example Oliveira et al. (2014) and Asiaei et al. (2019) reported insignificant results while Amini and 
Bakri (2015) reported a significant result. Specifying the actual roles of government and measuring it completely can help resolve the conflicting results and conspicuously reveal the type being reported in the literature. Although, Malaysian government has supported SMEs from both financial and non-financial aspects, this study chooses government financial support because Malaysian government has provided huge financial support for CC adoption by SMEs and the effect is yet to be categorically explored. For instance, through the Multimedia Development Corporation (MDeC) Malaysia, government of Malaysia offered a six-month refund on the subscription or RM1,500 and below of the total subscription for any type of SaaS such as cloud ERP from one of the Malaysia Multimedia Super Corridor (MSC) grade firms (Hassan, 2017; Hassan et al., 2017). An annual incentives of 250 USD was also introduced by the $\mathrm{CC}$ adoption programme initiated by the Malaysian government to incentivize local SMEs to embrace SaaS business cloud applications such as enterprise resource management (ERP), customer relationship management (CRM), content management systems (CMS) etc., rendered by local SaaS vendors (Rosen et al., 2015). Hence, this study conceptualises GS in terms of financial support to verify whether it has influence on cloud ERP adoption. Moreover, SMEs are mostly cash-strapped (Marston et al., 2011; Seethamraju, 2013; 2015) and would be more willing to adopt $\mathrm{CC}$ when financial incentive is provided.

\subsection{Strategic Consequences of Cloud ERP Adoption}

\subsubsection{Competitive Advantage (CA)}

Scholars and practitioners have shown great interest in understanding how CA could be created through different ways such as IT implementation, human resources capabilities, diversification, mergers and acquisition and so on (Breznik, 2012; Lee, 2015). Big and small organisations in developed and developing economies can speedily become strong competitors while using IT to create CA and become market leaders (Mustafa, 2015). Their determination to use IT as a means of gaining CA is motivated by their need to deliver cheap and quality products and services, heterogeneous products and services, capability to focus on a specific market segment, facilitate strategic planning and improve on the innovative practices of the organisation (Agwu and Murray, 2015; Chiu and Yang, 2019; Keller and Von der Gracht, 2014).

Some studies have examined how different types of IT can be a source of CA. Shehata and Montash (2019) developed and empirically examined an holistic model that attempted to discover the factors that determine CA of executing e-business in the third world countries (Middle East and North Africa). The result indicated that ICT driven customer relationships and environmental forces (e-business constructs) were positively significant to $\mathrm{CA}$ and e-business barriers mediated the relationships. Soliman and karia (2017) conceptually studied how successful ERP adoption in higher learning institution in Egypt could help them gain CA. Although, the study was not empirically validated, the authors established that ERP successful adoption by higher institutions in Egypt could make them gain CA because of the cheap standard 
educational services and also ERP system enabled effective resources use. Bilgihan and Wang, (2016) used semi-interview technique to gather data from CTO/CIOs and vice presidents of hotels, CEOs of technology vendors of hospitality and academics whose area is hospitality technology research in the US. The findings show that CA gained as a result of IT is achievable when hotels logically combine all existing technologies in the organisation in a way that generates synergy. A study found that cloud absorptive capacity and cloud usage positively and significantly influenced CA in diverse company sizes and industries internationally using online survey (Chang et al., 2019).

\subsubsection{Organisational Performance}

Organisational performance and its improvement are considered the central part of corporate strategic management and so most of the efforts of researchers in this field are directed to this aspect (Tseng and Lee, 2014; Masa'deh , Tarhini, Al-Dmour, and Obeidat, 2015). Empirically, evidence abound on the link between IT and firm performance. Lucia-Palacios, Bordonaba-Juste, Polo-Redondo and Grünhagen.(2014) reported a significant effect of implementing e-business (internal integration and external diffusion) on organisational performance (market share, profitability and sales volume) in US and Spanish firms. Furthermore, Gangwar (2017) examined the CC usage and organisational performance relationship in large and small manufacturing firms in India. The TOE framework and RBV were integrated and the results revealed that all the TOE factors were critical antecedents of $\mathrm{CC}$ usage. $\mathrm{CC}$ usage in turn was positively significant with organisational performance with firm size moderating actual usage and performance. Sallehudin, Razak and Ismail (2017) examined implementation of $\mathrm{CC}$ on the performance of agencies from the Malaysian public sector. The study revealed that technological and organisational factors and human characteristics had a significant effect on CC implementation and CC implementation impacted significantly and positively on operational effectiveness. Similarly, a Malaysian study found that performance expectancy, firm size, absorptive capacity of $\mathrm{CC}$ had a positively significant influence on innovativeness which in turn positively influenced performance of manufacturing firms (Ooi, Lee, Tan, Hew, and Hew, 2018).

Bruque-Cámara et al. (2016) analysed the effect of community CC on supply chain integration (informational and physical integration). The combined effect of community CC and supply chain integration on firms' operational results were also analysed. The results indicated that community $\mathrm{CC}$ exerted a positive and significant effect both on the supply chain integration and on operational performance in Spain. Based on prior studies on the consequences of IT/CC, most of the past research approached it in a fragmented manner especially $\mathrm{CA}$ and firm performance phenomenon. Meanwhile, the foremost proposition is that $\mathrm{CA}$ is a prelude to superior performance (Barney, 2001; Grant, 1991; Sigalas and Economou, 2013), and in all of the leading strategic management theories, a firm will achieve CA first before superior performance (Sigalas and Papadakis, 2018). To illustrate, RBV theory for example, suggests that tangible and intangible resources that are valuable, rare, inimitable and 
non substitutable (VRIN) (Barney, 1991) facilitate firms to grow and maintain competitive advantages (Essel, Adams, and Amankwah, 2019; Mohamad Radzi, Mohd Nor, and Mohezar Ali, 2017), and make use of these resources and CA for better firm performance (Madhani, 2010; Grant, 1991; Wernerfelt, 1984). Thus, a firm that attains a CA is most likely to exhibit a superior performance. In that light, the association between firm performance and competitive advantage is symbiotic (Breznik, 2012) and this study investigates both jointly and indirectly.

\section{Conceptual Framework and Hypotheses}

In this section, the relationship between the proposed key factors (FTM, TMSCM and GFS), cloud ERP adoption, CA and organisational performance are reviewed from the existing literature to support the proposed relationships in the conceptual framework (Figure 1). Basically, this framework has two parts which link the antecedents (FTM, TMSCM, GSF) of cloud ERP adoption with the strategic consequences (CA and organisational performance). In the first part (left-hand side), FTM, TMSCM and GSF serve as determining constructs of cloud ERP adoption. GSF also serves as a moderator construct between FTM, TMSCM and cloud ERP adoption. In the second part (right-hand side), cloud ERP adoption serves a determining construct of CA and firm performance. The CA also serves as a mediator construct between cloud ERP adoption and organisational performance.

Feature-task match refers to matching the qualities of the technology to the work requirements, that is to say, the capability of technology to support a successful task completion (Teo and Men, 2008). There are chances that the acceptance and utilisation of a new technology are higher when a higher compatibility level exist between the features of the technology and tasks to be executed (Ghani et al., 2017). It is not out of reflection that IT acceptance by users (organisational employees) may not be fruitful when they cannot notice a match between the IT and their work assignments, while it seems that the IT is useful (Cheng, 2019b; Zhou, Yu, and Wang, 2010). Fu et al. (2019) found that the fit between enterprise social media (ESM) characteristics and task requirements significantly had effect on ESM usage. Ghani et al. (2017) found FTM as the most influential factor that have significant effects on textile cyberpreneurs' behavioural intention to use cloud- based m-retail application. The fit between cloud ERP features and task (FTM) was found to have significant effects on users satisfaction, confirmation and perceived usefulness which in turn led to continued intention of cloud ERP usage (Cheng et al., 2019a). Therefore, it is predicted that when the cloud ERP features match the firm's tasks, employees will have a more positive attitude towards cloud ERP adoption. Hence the study proposes the following hypothesis:

\section{H1: Feature-task match positively influences cloud ERP adoption.}

Top Management Support on Change Management (TMSCM) is defined as purposeful set of activities by top management to facilitate, support, direct, authorise, 
and provide resources for organisational change throughout IT systems adoption, including ERP systems (Ifinedo, 2008; Wipfli LLP, 2014). Abdollahzadehgan, Che Hussin, Gohary and Amini (2013) found top mangement support as part of the most significant critical success factors of $\mathrm{CC}$ adoption using TOE in a qualitative study on SMEs in Malaysia. Kim, Jang and Yang (2017) reported top management support as a major driver of SaaS adoption. CC triggers organisational change and resistance to change has been found to hinder adoption and usage of CC (Gangwar, 2017; Hsu and Lin, 2016; Yeboah-Boateng and Essandoh, 2014) and TMS has been confirmed as an antidote for tackling organisational resistance and guaranteeing success in IT implementation (Elbanna, 2013). Dong at al. (2009) found TMSCM as a critical factor for enterprise systems implementation in Canadian universities in a case study. Thus, the following hypothesis is proposed:

\section{H2: Top management support on change management (TMSCM) positively influences} cloud ERP adoption.

GFS is defined as the support given by government to influence the adoption of innovative technology by SMEs through cloud-based services in addition to provision of firms with an additional source of funding (Huong and Cuong, 2019; Sandu and Gide, 2018). Government support for organisations can assume different dimensions, which may include direct investment, grants, tax incentives (Jugend et al., 2018) and policies. Most prior research found government support as key determinants that may influence innovative technology adoption particularly in countries that are classified as emerging economies (Amini, Sadat Safavi, Mirzaeyan Bahnamiri, Mirzaei Omran, and Amini, 2014; Ellahi, Hudzia, Li, Lindner, and Robinson, 2010). On GFS, Doh and Kim (2014) found that there was a significantly positive relationship between technology innovation and the Korean government's technology development assistance funds. Small business budgets a small amount for IT facilities, so government financial aid encourages the adoption of $\mathrm{CC}$ which boosts the performance of the whole SMEs sector (Raut, Gardas, Jha, and Priyadarshinee, 2017). Thus, the following hypothesis is proposed:

\section{H3: GFS positively influences cloud ERP adoption.}

The literature suggests that the TOE model lacks the moderator effect in IT research and its implication in technology adoption regarding the probable environmental factors (Alsaad, Mohamad, and Ismail, 2018; Oliveira et al., 2019; Venkatesh and Bala, 2012). Assessing the moderating influences of the environmental factors (such as government financial support) over the technological and organisational factors provides a more contextualised analysis of the topic under study and the TOE framework itself (O’Leary-Kelly, Martocchio, and Frink, 1994; Oliveira, Martins, Sarker, Thomas, and Popovič, 2019). Ramanathan, Ramanathan and Ko (2014) in the RFID adoption context show that there was a strong government support moderation relationship between RFID usability and its adoption. Similarly, in SaaS adoption, Oliveira et al. (2019) used the TOE framework, tested and confirmed the moderating 
effect of the environmental context using the institutional theory variables (mimetic, coercive and normative pressure). Kim et al. (2018) found that government financial incentive positively moderated the relationship between perceived value and electric vehicle adoption in Korea. Based on the literature evidence, GFS is expected to strengthen the relationship between cloud ERP adoption and the technology (TMSCM) and organisation factors (FTM). Hence, the following hypotheses are proposed:

H4: GFS moderates the relationship between TMSCM and cloud ERP adoption.

H5: GFS moderates the relationship between FTM and cloud ERP adoption.

Figure 1. Proposed Conceptual Framework with Hypotheses

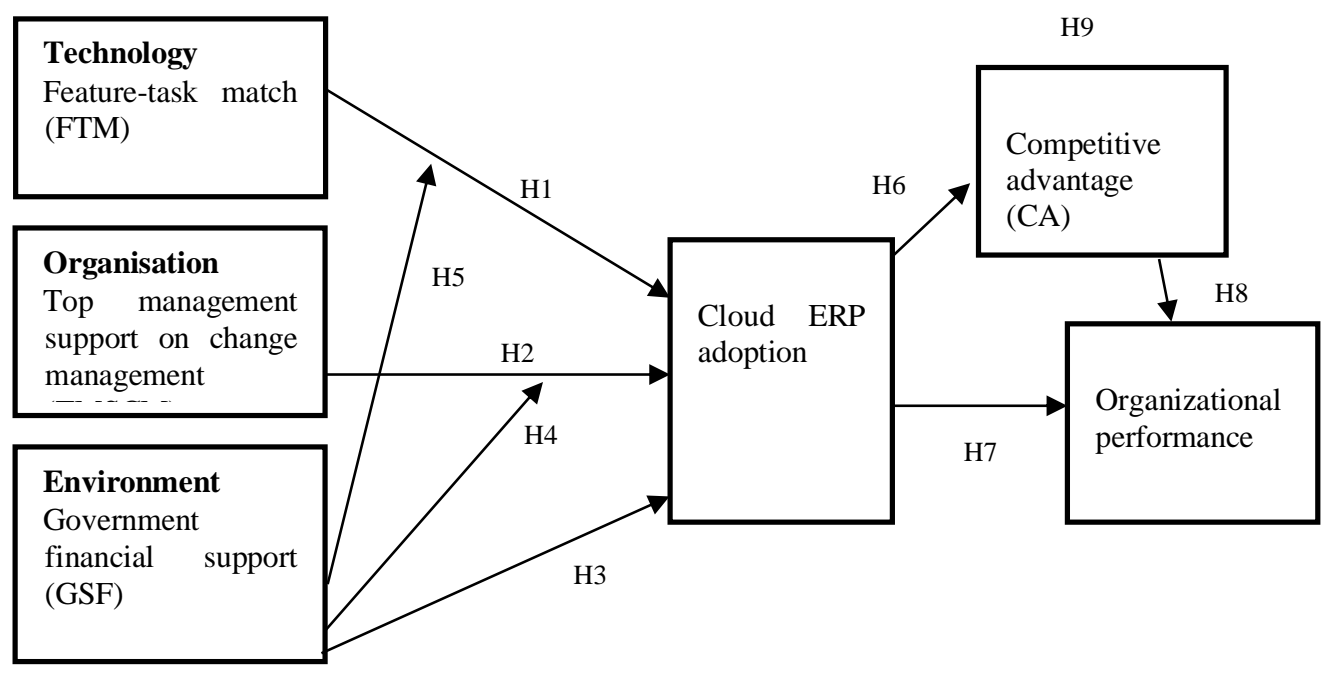

Source: Developed by authors.

Adopting $\mathrm{CC}$ contributes to changing the businesses operations in order to achieve CA (Chen, Jaw, and Wu 2016). CC helps companies to cut IT investment by providing on-demand computing power to allow rapid implementation, fewer IT staff, low maintenance, and lower overall IT expenditure (Lin and Chen, 2012; Yang and Tate, 2012). Internet adoption was positively significant to gaining CA by firms in diverse sectors in Singapore (Teo and Pian, 2003). Chang et al. (2019) found that cloud absorptive capacity and cloud usage positively and significantly influenced CA of firms. Hence, cloud ERP adoption can enable firms gain CA. Thus, the following hypothesis is proposed:

H6: Cloud ERP adoption positively influences competitive advantage.

IT adoption generally supports firms to achieve a better performance such as to gain market share, higher productivity, better product and services innovation, reliable 
customer-oriented position and improved response to market changes (Cardona, Kretschmer, and Strobel, 2013; Hall, Lotti, and Mairesse, 2013; Tran et al., 2014). Adopting a new technology is only vital if it really improves the performance of business organisations (Yunis, Tarhini, and Kassar, 2018). Effectively adopting and aligning an IT resource to enhance the organisational core competencies boosts firm performance (Ilmudeen, Bao, and Alharbi, 2019). The study of Gupta, Qian et al. (2018) showed that both cloud ERP and big data had a positive and significant impact on operational and market performance. Hunton, Lippincott and Reck (2003) compared the financial performance of 126 ERP adopters and non-adopters firms obtained by a past study and database (Compustat) in the US. Results of the study signified that return on assets (ROA), return on investment (ROI) and asset turnover (ATO) were significantly improved over a three-year period for adopters, in comparison to non-adopters. Further, the financial performance of non-adopters deteriorated over time whereas it held steady for adopters. Hence, the following hypothesis is proposed.

\section{H7: Cloud ERP adoption positively influences organisational performance.}

Given that the foremost aim of enterprises is to make high financial returns, achieving this goal can be aided through gaining a sustainable competitive advantage (Ma, 2000; Majeed, 2011). Meaning, the main objective of many business is to attain a competitive advantage that is sustainable (Saeidi, Sofian, Saeidi, Saeide, and Saiedi, 2015) and superior organisational performance. CA is the competence/set of competencies or resource/set of resources that give a firm a relative benefit on its business rivals which subsequently leads to higher relative performance (Wiggins and Ruefli, 2002). Organisational performance is defined as fulfilling all tasks which are necessary to reach organisational goals (e.g. increasing profits) (Kopia, 2019).

Rationally, when a firm demonstrates a superior performance, that is, it commands above-average economic rents, in that case the firm has achieved CA, an evidence that the relationship between $\mathrm{CA}$ and organisational performance is mutual (Breznik, 2012). The mutuality between CA and organisational performance has been confirmed in the extant literature. Lee (2015) confirmed the significant relationship between CA and firm market performance of the women entrepreneur in small-sized business in Korea. Potjanajaruwit (2018) found that CA significantly had an effect on SMEs start-ups perfomance. Handoko, Aryanto and So (2015) found that ERP showed a significant and positive relationship to CA and CA subsequently had significant impact on organisational performance. Thus, the following hypothesis is proposed:

\section{H8: Competitive advantage positively influences organisational performance.}

Most leading strategic management theories classify CA as an intermediate construct to performance (Sigalas and Papadakis, 2018). For instance, the RBV states that an organisation is very likely to achieve a superior performance from CA captured by the 
distinctive capabilities and resources of the organisation (Barney,1991; Wernerfelt, 1984). Besides that, the dynamic capabilities theory by Teece, Pisano and Shuen (1997) claims that CA developed from the dynamic capabilities of the firm can result to superior performance. In the commercial banking context, Kamukama, Kyomuhangi, Akisimire and Orobia (2017) found a partial significant mediation impact of CA in the relationship between competence and financial performance in Uganda. Saeidi et al. (2015) established the mediating effect of CA in the relationship between corporate social responsibility (CSR) and financial performance. Similarly, Cantele and Zardini (2018) in the CSR context found CA to be a mediator that positively contributed to the financial performance of Italian manufacturing SMEs. Although the above mediation evidences of CA on performance are outside the ITCA-Organisational performance context, nevertheless they provide insights on the CA mediation effect to performance. Furthermore, prior studies have been inconclusive on the relationship between IT and firm performance, (Sigalas and Economou, 2013; Sigalas and Papadakis, 2018; Breznik, 2012), hence a basis to investigate the mediating effect of $\mathrm{CA}$ in the relationship between cloud ERP adoption and organisational performance. Hence, the following hypothesis is proposed:

H9: Competitive advantage mediates the relationship between cloud ERP adoption and organisational performance.

\section{Research Methodology}

The target population of this study are the manufacturing SMEs in Malaysia. Toplevel managers such as senior IT managers, information technology officer (ITO), chief information officer (CIO) and SMEs owners constitute the unit of analysis. They are suitable respondents for this study since they are usually more knowledgeable about issues concerning CC adoption and its business benefits which are strategic in nature, than a lower-level or operational employee. The sample size is derived from the use of Krejcie and Morgan's (1970) sample size determination formula which is 382. In this research, the stratified random sampling is used. According to Department of Statistics, Malaysia (2016), Selangor, Kuala Lumpur and Johor have the largest number of SMEs in the range of $19.8 \%, 14.7 \%$ and $10.8 \%$ respectively. Hence, each serves as a stratum to draw the sample size. Survey method with the aid of online and paper-based questionnaire will be employed to reach a larger potential respondents.

The questionnaire consists of the demographic profile part and the major constructs' part which has 63 questions in total. The second part of the questionnaire will be measured with a 5-point Likert scale ranging from "strongly disagree to strongly agree". The English version will be translated back to back into Malay language for understandability by language experts, after which it will be pre-tested by two senior IS faculty members and one industry expert. The pilot-test will be carried out by 30 manufacturing SMEs that will be excluded from the main sample. All items of the constructs are adapted from previous related studies on IT adoption and consequences. For data analysis, descriptive statistics and Structural Equation Modelling (SEM) 
techniques will be used and SPSS 23.0 and SMART-PLS 3.0 are the software to be employed.

\section{Discussion, Conclusion and Limitation}

This study is on-going and the proposed conceptual framework will be empirically validated with data collected from manufacturing SMEs in Malaysia. This research is planned to comprehend the holistic cause and effect of cloud ERP adoption in the manufacturing SMEs in Malaysia. Therefore, it will contribute significantly to the adoption and strategic management literature.

First, this research includes only key contextual factors (FTM, TMSCM and GFS) as antecedents to cloud ERP adoption in the TOE model which were not altogether considered by prior studies. This research has the potential to help SMEs' managers in manufacturing sector to avoid one size fits all of cloud ERP and opt for the one that aligns with their tasks. Change resistance erupted by new technology adoption can be effectively managed by managers and the effect of GFS on CC adoption will be clearly exposed by this present study to the best of our knowledge for the first time, especially in Malaysia SMEs context.

Second, cloud ERP adoption is further examined simultaneously on strategic consequences- CA and organisational performance, since there exists a symbiotic relationship between these two strategic constructs based on the propositions of most strategic management theories. The relative new simultaneous investigation of cloud ERP on CA and firm performance and the mediation effect of CA between cloud ERP and firm performance contributes significantly to the RBV theory and practically managers can analyse cloud ERP's ability to exhibit dual, single and/or indirect strategic benefits in their organisations.

Third, the complete motivation and effect of adopting an IT like cloud ERP are embedded in a single research model for clarity and proper understanding, rather than partially examining the relationships as common in extant literature.

Fourth, the predictive capability of the TOE framework is strengthened through the inclusion of FTM, thereby addressing the shortcomings of individual characteristics and TTF the TOE lacks.

Lastly, policy makers will gain insights into the area to focus their support for SMEs to successfully adopt cloud ERP which can enhance their competitiveness and performance for higher GDP contribution, since SMEs make 98.5\% of the business population in Malaysia (SME Corp Malaysia, 2016).

Although this study seeks to investigate key factors of cloud ERP adoption and how they subsequently influence CA and firm performance simultaneously and indirectly, it also has some limitations. Factors included as antecedents to cloud ERP are not 
exhaustive, future studies may consider examining more novel key factors. This study criticized prior studies for not differentiating between GFS and government nonfinancial support in IT adoption, yet only the GFS is focused to prove its impact on cloud ERP adoption. Future studies can include both in their framework and test and compare their effects on cloud ERP adoption. Other types of TMS such TMSresource, TMS-vision sharing, TMS-communication and more can be examined individually to identify the most significant for cloud ERP adoption. Even though this study has holistically embedded key contextual factors and strategic consequences of cloud ERP adoption in a framework, future study may consider investigating the key contextual factors of cloud ERP adoption directly on CA and organisational performance.

\section{References:}

Abdollahzadehgan, A., Che Hussin, A.R., Gohary, M.M., Amini, M. 2013. The Organisational Critical Success Factors For Adopting Cloud Computing in SMEs. Journal of Information Systems Research \& Innovation, 4(1), 67-74.

Abolfazli, S., Sanaei, Z., Tabassi, A., Rosen, S., Gani, A., Khan, S.U. 2015. Cloud Adoption in Malaysia: Trends, Opportunities, and Challenges. IEEE Cloud Computing, 60-68.

Abugabah, A., Sanzogni, L., Alfarraj, O. 2015. Evaluating the Impact of ERP Systems in Higher Education. International Journal of Information \& Learning Technology, 32(1), 45-64. https://doi.org/10.1108/IJILT-10-2013-0058.

Agwu, E.M., Murray, P.J. 2015. Empirical Study of Barriers to Electronic Commerce Uptake by SMEs in Developing Economies. International Journal of Innovation in the Digital Economy, 6(2), 1-19.DOI: 10.4018/ijide.2015040101.

Ahmed, R., Azmi bin Mohamed, N. 2017. Development and Validation of an Instrument for Multidimensional Top Management Support. International Journal of Productivity \& Performance Management, 66(7), 873-895. DOI:10.1108/IJPPM-12-2015-0182.

AL-Shboul, M.A. 2018. Towards Better Understanding of Determinants Logistical Factors in SMEs for Cloud ERP Adoption in Developing Economies. Business Process Management Journal, BPMJ-01-2018-0004. DOI: 10.1108/BPMJ-01-2018-0004.

Alsaad, A., Mohamad, R., Ismail, N.A. 2018. The Contingent Role of Dependency in Predicting the Intention to Adopt B2B E-commerce. Information Technology for Development, 1-29. https://doi.org/10.1080/02681102.2018.1476830.

Amini, M., Bakri, A. 2015. Cloud Computing Adoption by SMEs in the Malaysia: A MultiPerspective Framework Based on DOI Theory and TOE Framework. Journal of Information Technology \& Information Systems Research (JITISR), 9(2), 121-135.

Amini, M., Sadat Safavi, N., Mirzaeyan Bahnamiri, R., Mirzaei Omran, M., Amini, M. 2014. Development of an Instrument for Assessing the Impact of Environmental Context on Adoption of Cloud Computing for Small and Medium Enterprises. Australian Journal of Basic Applied Sciences, 8(10), 129-135.

Amit, R., Schoemaker, P.J. 1993. Strategic Assets and Organizational rent. Strategic Management Journal, 13, 33-46.

Arteta, B.M., Giachetti, R.E. 2004. A Measure of Agility as the Complexity of the Enterprise System. Robotics \& Computer-Integrated Manufacturing, 20(6), 495-503.

Asiaei, A., Zairah, N., Rahim, A. 2019. A Multifaceted Framework for Adoption of Cloud Computing in Malaysian SMEs. DOI: 10.1108/JSTPM-05-2018-0053.

Awa, H., Baridam, D., Nwibere, B. 2015. Demographic Determinants of E-commerce 
Adoption: A Twist by Location Factors. Journal of Enterprise Information Management, 28(3), 325-346.

Awa, H.O., Ojiabo, O.U., Orokor, L.E. 2017. Integrated Technology-Organization-

Environment (T-O-E) Taxonomies for Technology Adoption. Journal of Enterprise Information Management, 30(6), 893-921. DOI: 10.1108/JEIM-03-2016-0079.

Azam, M.S. 2015. Diffusion of ICT and SME performance. Advances in Business Marketing \& Purchasing, 23A. https://doi.org/10.1108/S1069-096420150000023005.

Balaid, A., Abd Rozan, M., Abdullah, S. 2014. Conceptual Model for Examining Knowledge Maps Adoption in Software Development Organizations. Asian Social Science, 10(15), 119-132.

Barney, J.B. 1991. Firm Resources and Sustained Competitive Advantage. Journal of Management, 17(1), 99-121.

Barney, J.B. 2001. Resource-based Theories of Competitive Advantage: A Ten-year Retrospective on the Resource-Based View. Journal of Management, 27(6), 643-650.

Bass, B.M. 2008. The Bass Handbook of Leadership: Theory, Research, and Managerial Applications (4th ed.), The Free Press, New York, NY.

Bilgihan, A., Wang, Y. 2016. Technology Induced Competitive Advantage: A Case of US Lodging Industry. Journal of Hospitality and Tourism Technology, 7(1), 37-59. https://doi.org/10.1108/JHTT-01-2015-0001.

Boonstra, A. 2013. How Do Top Managers Support Strategic Information System Projects and Why Do they Sometimes Withhold this Support? International Journal of Project Management, 31(4), 498-512.

Breznik, L. 2012. Can Information Technology Be a Source of Competitive Advantage? Economic \& Business Review, 3(14), 251-269.

Bruque-Cámara, S., Moyano-Fuentes, J., Maqueira-Marín, J.M. 2016. Supply Chain Integration through Community Cloud: Effects on Operational Performance. Journal of Purchasing \& Supply Management, 22(2), 141-153. DOI: 10.1016/j.pursup.2016.04.003.

Cai, S., Jun, M., Yang, Z. 2010. Implementing Supply Chain Information Integration in China: The Role of Institutional Forces and Trust. Journal of Operations Management, 28(3), 257-268. https://doi.org/10.1016/j.jom.2009.11.005.

Cantele, S., Zardini, A. 2018. Is Sustainability a Competitive Advantage for Small Businesses? An Empirical Analysis of Possible Mediators in the SustainabilityFinancial Performance Relationship. Journal of Cleaner Production, 182, 166-176. https://doi.org/10.1016/j.jclepro.2018.02.016.

Cardona, M., Kretschmer, T., Strobel, T. 2013. ICT and Productivity: Conclusions from the Empirical Literature. Information Economics \& Policy, 25(3), 109-125.

Chang, Y.W., Hsu, P.Y., Huang, S.H., Chen, J. 2019. Determinants of Switching Intention to Cloud Computing in Large Enterprises. Data Technologies \& Applications. Retrieved from: https://doi.org/10.1108/DTA-12-2018-0104.

Chen, Y.Y.K., Jaw, Y.L., Wu, B.L. 2016. Effect of Digital Transformation on Organisational Performance of SMEs: Evidence from the Taiwanese Textile Industry's Web Portal. Internet Research, 26(1), 186-212. https://doi.org/10.1108/IntR-12-2013-0265.

Cheng, Y.M. 2019a. A Hybrid Model for Exploring the Antecedents of Cloud ERP Continuance: Roles of Quality Determinants and Task-Technology Fit. International Journal of Web Information Systems, 15(2), 215-235. DOI:10.1108/IJWIS-07-20180056.

Cheng, Y.M. 2019b. How Does Task-Technology Fit Influence Cloud-Based E-Learning Continuance and Impact? Education \& Training, 61(4), 480-499. 
https://doi.org/10.1108/ET-09-2018-0203.

Chiu, C.N., Yang, C.L. 2019. Competitive Advantage and Simultaneous Mutual Influences between Information Technology Adoption and Service Innovation: Moderating Effects of Environmental Factors. Structural Change \& Economic Dynamics, 49, 192205. https://doi.org/10.1016/j.strueco.2018.09.005.

D'Ambra, J., Wilson, C.S. 2013. Application of the Task-Technology Fit Model to Structure and Evaluate the Adoption of E-Books by Academics. Journal of The American Society for Information Science \& Technology, 64(1), 48-64.

Department of Statistics, Malaysia. 2016. Economic Census 2016. Available at https://www.dosm.gov.my/v1/index.php?r=column/cone\&menu_id=RDRSYVRzK1JF cmh0dm5mV1I4NkFJQT09.

Dicksen, P.R. 1996. The Static and Dynamic Mechanics of Competitive Theory. Journal of Marketing, 60, 102-106.

Doh, S., Kim, B. 2014. Government Support for SME Innovations in the Regional Industries: The Case of Government Financial Support Program in South Korea. Research Policy, 43(9), 1557-1569. https://doi.org/10.1016/j.respol.2014.05.001.

Dong, L., Neufeld, D., Higgins, C. 2009. Top Management Support of Enterprise Systems Implementations. Journal of Information Technology, 24(1), 55-80. https://doi.org/10.1057/jit.2008.21.

Elbanna, A. 2013. Top Management Support in Multiple-Project Environments: An InPractice View. European Journal of Information Systems, 22(3), 278-294.

Ellahi, T., Hudzia, B., Li, H., Lindner, M.A., Robinson, P. 2010. The Enterprise Cloud Computing Paradigm, Cloud Computing: Principles and Paradigms, 97-118. Wiley Series on Parellel and Distributed Computing [online]. Available at: http://lms.ctl.cyut.edu.tw/sysdata/81/33281/doc/01918f578f160703/attach/1910871.pdf

Elragal, A., El Kommos, M. 2012. In-house Versus In-Cloud ERP Systems: A Comparative Study. Journal of Enterprise Resource Planning Studies, 1.

Essel, B.K.C., Adams, F., Amankwah, K. 2019. Effect of Entrepreneur, Firm, and Institutional Characteristics on Small-scale Firm Performance in Ghana. Journal of Global Entrepreneurship Research, 9(1). https://doi.org/10.1186/s40497-019-0178-y.

Fook Ming, C., Kim On, C., Rayner, A., Tse Guan, T., Patricia, A. 2018. The Determinant Factors Affecting Cloud Computing Adoption by Small And Medium Enterprises (SMEs) in Sabah, Malaysia. Journal of Telecommunication, Electronic \& Computer Engineering, 10(3-2), 83-88.

Gangwar, H. 2017. Cloud Computing Usage and Its Effect on Organizational Performance. Human Systems Management, 36(1), 13-26. https://doi.org/10.3233/HSM-171625.

Gangwar, H., Date, H., Ramaswamy, R. 2015. Understanding Determinants of Cloud Computing Adoption Using an Integrated TAM-TOE Model. Journal of Enterprise Information Management, 28(1), 107-130. https://doi.org/10.1108/JEIM-08-2013-0065

Garrison, G., Wakefield, R.L., Kim, S. 2015. The Effects of IT Capabilities and Delivery Model on Cloud Computing Success and Firm Performance for Cloud Supported Processes and Operations. International Journal of Information Management, 35(4), 377-393.

Gartner, Inc. 2018. Gartner Says 28 Percent of Spending in Key IT Segments Will Shift to the Cloud by 2022. Retrieved from:https://www.gartner.com/en/newsroom/pressreleases/2018-09-18-gartner-says-28-percent-of-spending-in-key-IT-segments-willshift-to-the-cloud-by-2022.

Ghani, W.S., Di, W.A., Khidzir, N.Z., Guan, T.T., Ismail, M. 2017. Analysis on Factors Influencing Textile Cyberpreneur's Intention to Adopt Cloud-Based m-Retail 
Application. Procedia Computer Science, 124, 345-353.

https://doi.org/10.1016/j.procs.2017.12.164.

Goodhue, D.L., Thompson, R.L. 1995. Task-technology Fit and Individual Performance.

MIS Quarterly: Management Information Systems, 19(2), 213-233.

https://doi.org/10.2307/249689.

Grant, R.M. 1991. The Resource-Based Theory of Competitive Advantage: Implications for Strategy Formulation. California Management Review, 33(3), 114-135. https://doi.org/10.2307/41166664.

Grant, R.M. 1996. Towards a Knowledge-based Theory of the Firm. Strategic Management Journal, 17, 109-122.

Gupta, S., Kumar, S., Singh, S.K., Foropon, C., Chandra, C. 2018. Role of Cloud ERP on the Performance of an Organization: Contingent Resource-based View Perspective. International Journal of Logistics Management, 29(2), 659-675. https://doi.org/10.1108/IJLM-07-2017-0192.

Gupta, S., Misra, S.C. 2016. Moderating Effect of Compliance, Network, and Security on the Critical Success Factors in the Implementation of Cloud ERP. IEEE Transactions on Cloud Computing, 4(4), 440-451. https://doi.org/10.1109/TCC.2016.2617365.

Gupta, S., Qian, X., Bhushan, B., Luo, Z. 2018. Role of Cloud ERP and Big Data on Firm Performance: A Dynamic Capability View Theory Perspective. Management Decision, 57(8), 1857-1882. https://doi.org/10.1108/MD-06-2018-0633.

Gutierrez, A., Boukrami, E., Lumsden, R. 2015. Technological, Organisational and Environmental Factors Influencing Managers' Decision to Adopt Cloud Computing in the UK. Journal of Enterprise Information Management, 28(6), 788-807. https://doi.org/10.1108/JEIM-01-2015-0001.

Hall, B.H., Lotti, F., Mairesse, J. 2013. Evidence on the Impact of R\&D and Ict Investments on Innovation and Productivity in Italian Firms. Economics of Innovation \& New Technology, 22(3), 300-328.

Handoko, B.L., Aryanto, R., So, I.G. 2015. The Impact of Enterprise Resources System and Supply Chain Practices on Competitive Advantage and Firm Performance: Case of Indonesian Companies. Procedia Computer Science, 72, 122-128. https://doi.org/10.1016/j.procs.2015.12.112.

Hasnan, L. 2019. Singapore Leads in Cloud Tech. The Asean Post. Retrieved from:https://theaseanpost.com/article/singapore-leads-cloud-tech.

Hassan, H. 2017. Organisational Factors Affecting Cloud Computing Adoption in Small and Medium Enterprises (SMEs) in Service Sector. Procedia Computer Science, 121, 976981. https://doi.org/10.1016/j.procs.2017.11.126.

Hassan, H., Mohd Nasir, M.H., Khairudin, N., Adon, I. 2017. Factors Influencing Cloud Computing Adoption in Small and Medium Enterprises. Journal of ICT, 16(1), 21-41.

Henderson, D., Sheetz, S., Trinkle, B. 2012. The Determinants of Inter-organizational and Internal In-house Adoption of XBRL: A Structural Equation Model. International Journal of Accounting Information Systems, 13(2), 109-140.

Hossain, M.A., Quaddus, M. 2011. The Adoption and Continued Usage Intention of RFID: An Integrated Framework. Information Technology \& People, 24(3), 236-256.

Hsu, C.L., Lin, J.C.C. 2016. Factors Affecting the Adoption of Cloud Services in Enterprises. Information Systems and E-Business Management, 14(4), 791-822. https://doi.org/10.1007/s10257-015-0300-9.

Huong, V.V., Cuong, L.K. 2019. Does Government Support Promote SME Tax Payments? New Evidence from Vietnam. Finance Research Letters, 1-8. https://doi.org/10.1016/j.frl.2018.11.017. 
Hunton, J.E., Lippincott, B., Reck, J.L. 2003. Enterprise Resource Planning Systems: Comparing Firm Performance of Adopters and Nonadopters. International Journal of Accounting Information Systems, 4(3), 165-184. https://doi.org/10.1016/S14670895(03)00008-3.

Ifinedo, P. 2008. Impacts of Business Vision, Top Management Support, and External Expertise on ERP Success. Business Process Management Journal, 14(4), 551-568. https://doi.org/10.1108/14637150810888073.

Ilmudeen, A., Bao, Y., Alharbi, I.M. 2019. How Does Business-IT Strategic Alignment Dimension Impact on Organisational Performance Measures. Journal of Enterprise Information Management, 32(3), 457-476.

Jugend, D., Jabbour, C.J.C., Alves Scaliza, J.A., Rocha, R.S., Junior, JA.G., Latan, H., Salgado, M.H. 2018. Relationships among Open Innovation, Innovative Performance, Government Support and Firm Size: Comparing Brazilian Firms Embracing Different Levels of Radicalism in Innovation. Technovation, 74-75, 54-65. https://doi.org/10.1016/j.technovation.2018.02.004.

Kamasak, R. 2017. The Contribution of Tangible and Intangible Resources, and Capabilities to a Firm's Profitability and Market Performance. European Journal of Management \& Business Economics, 26(2), 252-275.

Kamukama, N., Kyomuhangi, D.S., Akisimire, R., Orobia, L.A. 2017. Competitive Advantage: Mediator of Managerial Competence and Financial Performance of Commercial Banks in Uganda. African Journal of Economic \& Management Studies, 8(2), 221-234. https://doi.org/10.1108/AJEMS-10-2016-0142.

Karkonasasi, K., Baharudin, A.S., Esparham, B., Mousavi, S.A. 2016. Adoption of Cloud Computing among Enterprises in Malaysia. Indian Journal of Science \& Technology, 9(48), 1-7. https://doi.org/10.17485/ijst/2016/v9i48/88128.

Kopia, J. 2019. Effective Implementation of Management Systems. Sustainable Management, Wertschöpfung Und Effizienz. doi: 10.1007/978-3-658-26509-0.

Krejcie, R.V., Morgan, D.W. 1970. Determining Sample Size for Research Activities. Educational \& Psychological Measurement.

Lee, W.J. 2015. Social Capital as a Source of Business Advantages for a Woman Entrepreneur in the Context of Small-size Business. Asian Social Science, 11(12), 155 167. https://doi.org/10.5539/ass.v11n12p155.

Lee, J. 2018. Propelling Smes in the Digital World. The Star Online. Retrieved from:https://www.thestar.com.my/business/smebiz/2018/12/24/propelling-smes-in-thedigital-world/.

Lin, A., Chen, N.C. 2012. Cloud Computing as an Innovation: Percepetion, Attitude, and Adoption. International Journal of Information Management, 32(6), 533-540.

Liu, S. 2020. Cloud Enterprise Resource Planning (ERP) Market Revenue Worldwide in 2018 and 2023. Statista. Retrieved from:https://www.statista.com/statistics/681753/worldwide-cloud-erp-softwarerevenue/.

Lucia-Palacios, L., Bordonaba-Juste, V., Polo-Redondo, Y., Grünhagen, M. 2014. E-business Implementation and Performance: Analysis of Mediating Factors. Internet Research, 24(2), 223-245. https://doi.org/10.1108/IntR-09-2012-0195.

Ma, H. 2000. Competitive Advantage and Firm Performance. Competitiveness Review: An International Business Journal Incorporating Journal of Global Competitiveness, 10(2), 15-32.

Madhani, P. 2010. Resource Based View (RBV) of Competitive Advantage: An overview. Based View: Concepts \& Practices, Pankaj. Retrieved from: 
http://papers.ssrn.com/sol3/papers.cfm?abstract_id=1578704.

Majeed, S. 2011. The Impact of Competitive Advantage on Organisational Performance. European Journal of Business \& Management, 3(4), 191-196.

Marston, S., Li, Z., Bandyopadhyay, S., Zhang, J., Ghalsasi, A. 2011. Cloud computing - The Business Perspective. Decision Support Systems, 51(1), 176-189. https://doi.org/10.1016/j.dss.2010.12.006.

Masa'deh, R., Tarhini, A., Al-Dmour, R., Obeidat, B. 2015. Strategic IT-business Alignment as Managers' Exploitative Strategies. European Scientific Journal, 11(7), 437-457.

Mehrotra, R. 2017. SMEs More Aware of Cloud Benefits. Microsoft Malaysia News Centre. Retrieved from:https://news.microsoft.com/en-my/2017/06/09/smes-aware-cloudbenefits/.

Mell, P., Grance, T. 2011. The NIST Definition of Cloud Computing. Retrieved from: http://nvlpubs.nist.gov/nistpubs/Legacy/SP/nistspecialpublication800-145.pdf.

Mohamad Radzi, K., Mohd Nor, M.N., Mohezar Ali, S. 2017. The Impact of Internal Factors on Small Business Success: A Case of Small Enterprises Under the FELDA Scheme. Asian Academy of Management Journal, 22(1), 27-55. https://doi.org/1 0.21315/aamj2017.22.1.2.

Mustafa, H.H. 2015. The Role of ICT Management to Achieve Organisational Innovation. International Journal of Organisational Innovation, 7(4), 48-56.

Nikookar, G., Yahya Safavi, S., Hakim, A., Homayoun, A. 2010. Competitive Advantage of Enterprise Resource Planning Vendors in Iran. Information Systems, 35(3), 271-277. https://doi.org/10.1016/j.is.2009.09.002.

Noordin, K.A. 2019 News: SMEs Still not Using Digitalisation Enablers. The Edge Markets. Retrieved from:https://www.theedgemarkets.com/article/news-smes-still-not-usingdigitalisation-enablers.

OECD. 2019. Southeast Asia Going Digital: Connecting SMEs. OECD, 1-158. Retrieved from: https://www.oecd.org/going-digital/southeast-asia-connecting-SMEs.pdf.

Oliveira, T., Martins, R., Sarker, S., Thomas, M., Popovič, A. 2019. Understanding SaaS Adoption: The Moderating Impact of the Environment Context. International Journal of Information Management, 49, 1-12. https://doi.org/10.1016/j.ijinfomgt.2019.02.009.

Oliveira, T., Martins, M.F. 2010. Understanding E-business Adoption across Industries in European Countries. Industrial Management \& Data Systems, 110(9), 1337-1354.

Oliveira, T., Thomas, M., Espadanal, M. 2014. Assessing the Determinants of Cloud Computing Adoption: An Analysis of the Manufacturing and Services Sectors. Information \& Management, 51(5), 497-510. https://doi.org/10.1016/j.im.2014.03.006.

Ooi, K.B., Lee, V.H., Tan, G.W.H., Hew, T.S., Hew, J.J. 2018. Cloud Computing in Manufacturing: The Next Industrial Revolution in Malaysia? Expert Systems with Applications, 93, 376-394. https://doi.org/10.1016/j.eswa.2017.10.009.

Oreg, S., Berson, Y. 2019. Leaders' Impact on Organizational Change: Bridging Theoretical and Methodological Chasms. Academy of Management Annals, 13(1), 272-307. https://doi.org/10.5465/annals.2016.0138.

Pathan, Z.H., Jianqiu, Z., Akram, U., Latif, Z., Khan, M.K., Tunio, M.Z. 2017. Essential Factors in Cloud-Computing Adoption by SMEs. Human Systems Management, 36(4), 261-275. https://doi.org/10.3233/HSM-17133.

Potjanajaruwit, P. 2018. Competitive Advantage Effects on Firm Performance: A Case Study of Startups in Thailand. Journal of International Studies, 11(3), 104-111. https://doi.org/10.14254/2071-8330.2018/11-3/9.

Premkumar, G. 2003. A Meta-analysis of Research on Information Technology Implementation in Small Business. Journal of Organizational Computing \& Electronic 
Commerce, 13(2), 91-121. https://doi.org/10.1207/S15327744JOCE1302_2.

Qian, L.Y., Baharudin, A.S., Kanaan-Jebna, A. 2016. Factors Affecting the Adoption of Enterprise Resource Planning (ERP) on Cloud among Small and Medium Enterprises (SMEs) in Penang, Malaysia. Journal of Theoretical \& Applied Information Technology, 88(3), 398-409. https://doi.org/1992-8645.

Ramanathan, R., Ramanathan, U., Ko, L.W.L. 2014. Adoption of RFID Technologies in UK Logistics: Moderating Roles of Size, Barcode Experience and Government Support. Expert Systems with Applications, 41(1), 230-236. https://doi.org/10.1016/j.eswa.2013.07.024.

Ratna, S., Astuti, E.S., Utami, H.N., Rahardjo, K., Arifin, Z. 2018. Characteristics of Tasks and Technology as a Driver of Task-technology Fit and the Use of the Hotel Reservation Information System. VINE Journal of Information \& Knowledge Management Systems, 48(4), 579-595. DOI:10.1108/VJIKMS-05-2018-0035.

Raut, R.D., Gardas, B.B., Jha, M.K., Priyadarshinee, P. 2017. Examining the Critical Success Factors of Cloud Computing Adoption in the MSMEs by Using ISM Model. Journal of High Technology Management Research, 28(2), 125-141. https://doi.org/10.1016/j.hitech.2017.10.004.

Reseller Malaysia. 2018 Malaysia's Cloud Adoption: Slow and Steady. Retrieved from:https://resellermalaysia.my/index.php/2018/01/29/malaysias-cloud-adoptionslow-and-steady/.

Rezaei, H., Karimi, B., Hosseini, S.J. 2016. Effect of Cloud Computing Systems in Terms of Service Quality of Knowledge Management Systems. Lecture Notes on Software Engineering, 4(1), 73.

Roberts, N., Grover, V. 2012. Leveraging Information Technology Infrastructure to Facilitate a Firm's Customer Agility and Competitive Activity: An Empirical Investigation. Joumal of Management Information Systems, 28(4), 231-269.

Rosen, S., Abolfazli, S., Tabassi, A., Gani, A., Khan, S.U., Sanaei, Z. 2015. Cloud Adoption in Malaysia: Trends, Opportunities, and Challenges. IEEE Cloud Computing, 2(1), 6068. https://doi.org/10.1109/mcc.2015.1.

Saeidi, S.P., Sofian, S., Saeidi, P., Saeidi, S.P., Saaeidi, S.A. 2015. How Does Corporate Social Responsibility Contribute to Firm Financial Performance? The Mediating Role of Competitive Advantage, Reputation, and Customer Satisfaction. Journal of Business Research, 68(2), 341-350. https://doi.org/10.1016/j.jbusres.2014.06.024.

Sallehudin, H., Razak, R.C., Ismail, M. 2017. Determinants and Impact of Cloud Computing Implementation in the Public Sector. Journal of Advances in Information Technology, 7(2), 245-251. https://doi.org/10.12720/jait.7.4.245-251.

Sandu, R., Gide, E. 2018. Technological, Organisational and Environmental (TOE) Factors that Influence the Adoption of Cloud Based Service SMEs in India. 2018 IEEE 11th International Conference on Cloud Computing (CLOUD), 866-870. https://doi.org/10.1109/CLOUD.2018.00123.

Seethamraju, R. 2013. Determinants of SaaS ERP Systems Adoption. Association for Information Systems AIS Electronic Library (AISeL), 6-18. Retrieved from: http://aisel.aisnet.org/pacis2013\%0Ahttp://aisel.aisnet.org/pacis2013/244.

Seethamraju, R. 2015. Adoption of Software as a Service (SaaS) Enterprise Resource Planning (ERP) Systems in Small and Medium Sized Enterprises (SMEs). Information Systems Frontiers, 17(3), 475-492. https://doi.org/10.1007/s10796-014-9506-5.

Shehata, G.M., Montash, M.A. 2019. Driving the Internet and E-Business Technologies to Generate a Competitive Advantage in Emerging Markets: Evidence from Egypt. Information Technology \& People. Available at: https://doi.org/10.1108/ITP-10-2017- 
0360.

Sigalas, C., Papadakis, V.M. 2018. Empirical Investigation of Relationship Patterns between Competitive Advantage and Superior Performance. Journal of Strategy \& Management, 11(1), 81-111. https://doi.org/10.1108/JSMA-01-2017-0010.

Sigalas, C., Pekka-Economou, V. 2013. Revisiting the Concept of Competitive Advantage: Problems and Fallacies Arising from Its Conceptualization. Journal of Strategy \& Management, 6(1), 61-80. https://doi.org/10.1108/17554251311296567.

SME Corporation and Huawei Technologies. 2018. Accelerating Malaysian Digital SMEs: Escaping the Computerisation Trap, Overcoming the Digitalisation Chasm of Malaysian SMEs, 78.

SME Corp. Malaysia 2016. SME Statistics. SMEs are the Backbone of the Economy. Retrieved from:http://www.smecorp.gov.my/index.php/en/policies/2015-12-21-09-0949/sme-statistics.

Soliman, M., Karia, N. 2017. Antecedents for the Success of the Adoption of Organizational ERP Among Higher Education Institutions and Competitive Advantage in Egypt. Technology \& Applied Science Research, 7(3), 1719-1724.

Son, I., Lee, D., Lee, J.N., Chang, Y.B. 2014. Market Perception on Cloud Computing Initiatives in Organizations: An Extended Resource-based View. Information \& Management, 51(6), 653-669.

SØrheller, V.U., HØvik, E.Jø., Hustad, E., Vassilakopoulou, P. 2018. Implementing Cloud ERP Solutions: A Review of Sociotechnical Concerns. Procedia Computer Science, 138, 470-477. https://doi.org/10.1016/j.procs.2018.10.065.

Teece, D.J., Pisano, G., Shuen, A. 1997. Dynamic Capabilities and Strategic Management. Strategic Management Journal, 18(7), 509-533.

Teng, L.J. 2020. SMEs Up against a Wall. The Edge Markets. Retrieved from:https://www.theedgemarkets.com/article/smes-against-wall.

Teo, T.S.H., Men, B. 2008. Knowledge Portals in Chinese Consulting Firms: A Tasktechnology Fit Perspective. European Journal of Information Systems, 17(6), 557-574.

Teo, T.S.H., Pian, Y. 2003. A Contingency Perspective on Internet Adoption and Competitive Advantage. European Journal of Information Systems, 12(2), 78-92. https://doi.org/10.1057/palgrave.ejis.3000448.

Tornatzky, L.G., Fleischer, M. 1990.The Processing of Technological Innovation. Lexington Books, Lexington, MA.

Tran, Q., Zhang, C., Sun, H., Huang, D. 2014. Initial Adoption Versus In- stitutionalization of E-Procurement in Construction Firms: An Empirical Investigation in Vietnam. Journal of Global Information Technology Management, 17(2), 91-116.

Tseng, S.M., Lee, P.S. 2014. The Effect of Knowledge Management Capability and Dynamic Capability on Organizational Performance. Journal of Enterprise Information Management, 27(2), 158-179.

Vu, K., Hartley, K., Kankanhalli, A. 2020. Predictors of Cloud Computing Adoption: A cross-country study. Telematics \& Informatics, 52, 101426. https://doi.org/10.1016/j.tele.2020.101426.

Yang, H., Tate, M. 2012. A Descriptive Literature Review and Classification of Cloud Computing Research. Communications of the Association of Information Systems, 31, 35-60. https://doi.org/10.1.1.261.3070.

Yeboah-Boateng, E.O., Essandoh, K.A. 2014. Factors Influencing the Adoption of Cloud Computing by Small and Medium Enterprises in Developing Economies. Citeseer, (4), 13-20. Retrieved from: http://citeseerx.ist.psu.edu/viewdoc/download?doi=10.1.1.685.4358\&rep=rep1\&type= 
pdf.

Yu, Y., Li, M., Li, X., Zhao, J.L., Zhao, D. 2018. Effects of Entrepreneurship and IT Fashion on SMEs' Transformation toward Cloud Service through Mediation of Trust. Information \& Management, 55(2), 245-257.

Yunis, M., Tarhini, A., Kassar, A. 2018. The Role of ICT and Innovation in Enhancing Organizational Performance: The Catalysing Effect of Corporate Entrepreneurship. Journal of Business Research, 88, 344-356. DOI:10.1016/j.jbusres.2017.12.030.

Wang, Y.M., Wang, Y.S., Yang, Y.F. 2010. Understanding the Determinants of RFID Adoption in the Manufacturing Industry. Technological Forecasting \& Social Change, 77(5), 803-815. https://doi.org/10.1016/j.techfore.2010.03.006.

Wang, N., Xue, Y., Liang, H., Wang, Z., Ge, S. 2019. The Dual Roles of the Government in Cloud Computing Assimilation: An Empirical Study in China. Information Technology \& People, 32(1), 147-170. https://doi.org/10.1108/ITP-01-2018-0047.

Wernerfelt, B. 1984. A Resource-based View of the Firm. Strategic Management Journal, 5, 171-180.

Wiggins, R.R., Ruefli, T.W. 2002. Competitive Advantage: Temporal Dynamics and the Incidence and Persistence of Superior Economic Performance. Organisation Science, 13(1), 82-105.

Wipfli LLP. 2014. Why Change Management is Key to Technology Implementation Success, 1-5. Retrievedfrom: https://www.acg.org/sites/files/Why Change Management is Key to Technology Implemenation Success Ebook.pdf.

Zamzeer, M., Alshamaileh, Y., Alsawalqah, H.I., Al-Hassan, M., Fannas, E.J.A., Almubideen, S.S. 2019. Determinants of Cloud ERP Adoption in Jordan: An Exploratory Study. International Journal of Business Information Systems.

Zhu, K., Kraemer, K.L. 2005. Post-adoption Variations in Usage and Value of E-business by Organizations: Cross-country Evidence from the Retail Industry. Information Systems Research, 16(1), 61-84. https://doi.org/10.1287/isre.1050.0045. 